\title{
ОСОБЛИВОСТІ ЛІПІДНОГО ОБМІНУ В ЖІНОК ІЗ ГОСТРИМ КОРОНАРНИМ СИНДРОМОМ БЕЗ ПІДЙОМУ СЕГМЕНТА ЗТ ЗАЛЕЖНО ВІД ГОРМОНАЛЬНОГО СТАТУСУ
}

Вступ. Роль порушень обміну ліпідів у процесі атерогенезу встановлено давно. Мало відомо про вплив дисліпідемій на розвиток ішемічної хвороби серця (IXC) ужінок. Існує уявлення про те, що вплив ендогенних естрогенів протягом фрертильного періоду життя жінок уповільнює маніфрестацію атеросклерозу в них і до настання менопаузи частота випадків IXC у жінок є нижчою. Особливу небезпеку в розвитку IXC у жінок становлять гіперхолестеринемія або атерогенна дисліпідемія і пов'язаний з нею ризик макросудинних уражень, зважаючи на тривалий безсимптомний перебіг і значну поширеність у жіночій популяції.

Мета дослідження - провести порівняльний аналіз показників ліпідного обміну в пацієнток із гострим коронарним синдромом без підйому сегмента ST (ГКСбпST) та практично здорових жінок залежно від гормонального статусу.

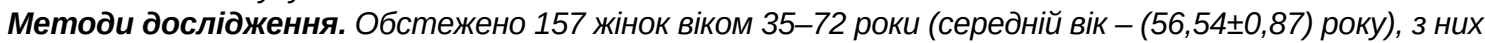
112 пацієнток із ГКСбпST (1-ша група) віком 39-72 роки (середній вік - $(58,52 \pm 0,99)$ року) та 45 практично здорових жінок (2-га група - група порівняння) віком 35-71 рік (середній вік - $(52,58 \pm 1,58)$ року). Визначали рівень жіночих статевих гормонів. Вивчали показники ліпідного обміну в жінок. Залежно від типу гормонального статусу жінок 1-ї та 2-ї груп було розподілено в підгрупи А і Б: 1A - 64 жінки віком 39-72 роки (середній вік - $(60,77 \pm 1,16)$ року) з ГКСбпST, 2A - 26 практично здорових осіб віком 42-71 рік (середній вік - $(58,64 \pm 2,18)$ року) з гормональними ознаками постменопаузи: рівнем естрадіолу <80 пмоль/л (21,79 пг/мл) та індексом ЛГ/ФСГ<1; 15 - 48 жінок віком 35-65 років (середній вік - $(52,29 \pm 1,63)$ року) 3 ГКСбпST, 2Б - 19 практично здорових осіб віком 35-58 років (середній вік - $(49,84 \pm 1,84)$ року) з рівнем естрадіолу >80 пмоль/л (21,79 пг/мл) та індексом ЛГ/ФСГ>1.

Результати й обговорення. Майже всі хворі жінки підгрупи 1 А мали рівень загального холестерину, більший 4 ммоль/л, що в 1,3 раза достовірно перевищувало такий же показник у пацієнток підгрупи 1Б $((95,31 \pm 2,64) \%(1 A)$ проти $(75,00 \pm 6,25) \%(15))$. Середній рівень холестерину ліпопротеїнів низької щіль-

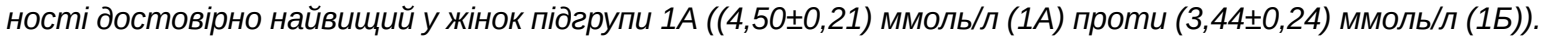
У $(73,43 \pm 5,52) \%$ пацієнток підгрупи 1А виявлено гіпертригліцеридемію, яку в 1,6 раза достовірно частіше реєстрували $((45,83 \pm 8,19) \%)$, ніж у хворих підгрупи 1Б. Частка пацієнток зі зниженими значеннями холестерину ліпопротеїнів високої щільності була майже в 1,5 раза меншою в підгрупі 1 A $((37,50 \pm 6,05) \%(1 A)$ проти $(52,08 \pm 7,21) \%(15))$. Середній рівень холестерину ліпопротеїнів високої щільності у підгрупі 1Б був достовірно нижчим порівняно з підгрупою $1 A((1,04 \pm 0,03)$ ммоль/л $(15)$ проти $(1,16 \pm 0,05)$ ммоль/л $(1 A))$. Поширеність цукрового діабету $((31,25 \pm 5,15) \%)$, куріння $((54,16 \pm 7,19) \%)$ та профресійно-шкідливої праці $((89,58 \pm 4,41) \%)$ виявилася достовірно вищою в пацієнток підгрупи 1Б.

Висновки. У хворих із ГКСбпST, незалежно від гормонального балансу жіночих статевих гормонів, більші поширеність та виразність дисліпідемій порівняно зі здоровими особами. Естрогенодефріцит у постменопаузальних жінок із ГКСбпST призводить до тяжких порушень ліпідного і жирового обміну, що сприяють розвитку ГКСбпST. Нижчі рівні холестерину ліпопротеїнів високої щільності, антиатерогенного холестерину ліпопротеїнів високої щільності у жінок зі збереженим естрогеновим фроном, порівняно 3 пацієнтками з естрогенодефріцитом, є наслідком вищої поширеності цукрового діабету $((31,25 \pm 5,15) \%)$, куріння $((54,16 \pm 7,19)$ \%) та професійно-шкідливої праці $((89,58 \pm 4,41) \%)$ поряд з наявністю традиційних фракторів ризику ГКСбпST у цих жінок.

КЛЮЧОВІ СЛОВА: гострий коронарний синдром; жінки; естрогенодефіцит; ліпідний обмін; дисліпідемії.

ВСТУП. У науковому положенні American HeartAssociation (2016) щодо лікування гострого коронарного синдрому (ГКС) серед осіб жіночої статі увагу акцентують на значному рівні захворюваності та вищій річній летальності від інфрарк(с) В. В. Процько, 2017 ту міокарда в жінок порівняно з чоловіками (26 проти 19 \% відповідно). В осіб жіночої статі гостру ішемічну хворобу серця (IXC) частіше виявляли у формі гострого коронарного синдрому без підйому сегмента ST (ГКСбпST). У таких пацієнток встановлено вищу поширеність та виразність 
таких фракторів ризику, як куріння, артеріальна гіпертензія, цукровий діабет, ожиріння, ниркова дисорункція, депресія тощо. Додатковими суто "жіночими" чинниками ризику в них вважають: настання менопаузи, гестаційний діабет та прееклампсію, гормонозамісну терапію, контрацепцію тощо. У результаті їх взаємодії з традиційними фракторами ризику спостерігають тяжчий перебіг IXC з істотними порушеннями серцевої діяльності, швидким прогресуванням серцевої недостатності, тривалішими госпіталізаціями, вищою внутрішньолікарняною летальністю та значно гіршим прогнозом порівняно з чоловіками [1]. Існує уявлення про те, що вплив ендогенних естрогенів протягом фрертильного періоду життя жінок уповільнює маніфрестацію атеросклерозу в них і до настання менопаузи частота випадків IXC у жінок $є$ нижчою.

Особливу небезпеку в розвитку IXC у жінок становлять гіперхолестеринемія або атерогенна дисліпідемія і пов'язаний з ними ризик макросудинних уражень, зважаючи на тривалий безсимптомний перебіг і значну поширеність у жіночій популяції. Роль порушень обміну ліпідів у процесі атерогенезу встановлено давно. Дані популяційних досліджень (MRFIT, LRC) доводять існування прямого зв'язку між рівнем у плазмі крові загального холестерину (3ХC) i/aбо холестерину ліпопротеїнів низької щільності (XC лПНЩ) та частотою захворюваності на IXC як серед жінок, так і серед чоловіків без ознак IXC [2]. Результати дослідження MONICA також свідчать про те, що існує пряма залежність між вмістом ХС ЛПНЩ та частотою розвитку інфраркту міокарда в жінок [3]. Результати низки епідеміологічних і клінічних досліджень підтверджують існування і вікових відмінностей ліпідного обміну в осіб обох статей. Ці відмінності найбільш помітні в жінок у пременопаузальний період. У них, завдяки естроген-прогестероновому фону, концентрація ЗХС, ХС лПНЩ і тригліцеридів (ТГ), як правило, нижча порівняно 3 чоловіками [4]. 3 віком рівень ЗХС у крові та ХС лПнЩ поступово зростає, і після настання менопаузи вміст у крові жінок атерогенних фрракцій ліпідів стрімко збільшується і суттєво перевищує такий у чоловіків відповідного віку. Аналогічно зростає вміст у крові ТГ. Вважають, що це пов'язано зі зниженням активності рецепторів до ліпопротеїнів на фроні гормональних змін. Впродовж усього життя для осіб жіночої статі характерна вища концентрація холестерину ліпопротеїнів високої щільності (ХС ЛПВЩ) порівняно з чоловіками. Проте в постменопаузальний період вона помірно знижується внаслідок зменшення рівнів естрогенів та активності печінкової ліпази [5].
Незалежно від настання календарної менопаузи в жінок може спостерігатися або збережений естрогеновий фон, або естрогенодефіцит. Тому окремо виділяють сучасні гормональні критерії настання менопаузи: зменшення рівня естрадіолу нижче 80 пмоль/л=21,79 пг/мл (гіпоестрогенія); різке зростання рівня фролікулостимулювального гормону при зниженні індексу лютеїнізуючий гормон/сролікулостимулювальний гормон<1 (ЛГ/ФСГ<1); зменшення індексу естрадіол/естрон<1; відносна гіперандрогенія; низький рівень інгібіну В яєчників, антимюлерового гормону і тестостероно-естрадіолозв'язувального глобуліну [6-8].

Мета дослідження - провести порівняльний аналіз показників ліпідного обміну в пацієнток із ГКСбпST та практично здорових жінок залежно від гормонального статусу.

МЕТОДИ ДОСЛІДЖЕННЯ. У дослідження включено 157 жінок пери- та постменопаузального періоду віком від 35 до 72 років (середній

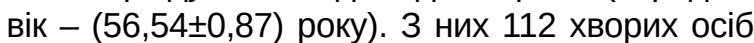
жіночої статі (1-ша група) віком від 39 до 72 років (середній вік - $(58,52 \pm 0,99)$ року) було госпіталізовано в інсрарктне відділення комунальної міської клінічної лікарні швидкої медичної допомоги м. Львова з приводу ГКСбпST. Діагноз верифріковано на підставі клініко-анамнестичних даних, результатів лабораторних та інструментальних досліджень (ЕКГ, коронароангіографії) відповідно до рекомендацій робочої групи ESC 3 лікування ГКС без стійкого підйому сегмента ST [9], національних рекомендацій Уніфікованого клінічного протоколу медичної допомоги "Гострий коронарний синдром без елевації сегмента ST (екстрена, первинна, вторинна (спеціалізована) медична допомога)" (2015) та наказу МО3 України від 03.03.2016 р. № 164 "Про затвердження та впровадження медико-технологічних документів зі стандартизації медичної допомоги при гострому коронарному синдромі без елевації сегмента ST" [10]. Групу порівняння (2-гу групу) становили 45 практично здорових жінок пери- та постменопаузального періоду віком від 35 до 71 року (середній вік - $(52,58 \pm 1,58)$ року).

Основними критеріями відбору хворих із ГКСбпST і практично здорових жінок були такі ознаки пери- та постменопаузи: затримка, відсутність чи порушення менструального циклу; порушення балансу жіночих статевих гормонів (ЛГ/ФСГ<1, естрадіол<21,79 пг/мл); нейровегетативні прояви перименопаузи (вазомоторні, метаболічні та психоемоційні), верифріковані за індексом менопаузи Купермана в модифрікації $€$ В. Уварової понад 12 балів [9]. У сироватці 
крові жінок методом імуноферментного аналізу визначали рівні статевих гормонів: естрадіолу, ФСГ та ЛГ. Серед сучасних ендокринних критеріїв клімактерію основними є: низький рівень естрадіолу (<80 пмоль/л=<21,79 пг/мл); висока концентрація ФСГ та співвідношення ЛГ/ФСГ<1 $[9,11,12]$. Залежно від типу гормонального статусу жінок 1-ї та 2-ї груп було розподілено в підгрупи А і Б. Підгрупу 1А становили 64 пацієнтки віком 39-72 роки (середній вік- $(60,77 \pm 1,16)$ року) з ГКСбпST, 2A - 26 практично здорових жінок віком 42-71 рік (середній вік - $(58,64 \pm 2,18)$ року) з гормональними ознаками постменопаузи: рівнем естрадіолу <80 пмоль/л (21,79 пг/мл) та індексом співвідношення ЛГ/ФСГ<1. До підгрупи 1Б увійшли 48 хворих жінок віком 35-65 років (середній вік - $(52,29 \pm 1,63)$ року) з ГКСбпST, 2Б - 19 практично здорових осіб жіночої статі віком 35-58 років (середній вік - $(49,84 \pm 1,84)$ року) з рівнем естрадіолу >80 пмоль/л (21,79 пг/мл) та індексом співвідношення ЛГ/ФСГ>1.

Для з'ясування стану ліпідного обміну визначали рівні ЗХС, ХС ЛПНЩ, холестерину ліпопротеїнів дуже низької щільності (ХС ЛПДНщ), ХС ЛПВЩ і ТГ. Концентрацію ЗХС і ТГ у сироватці крові визначали орерментативним методом за N. Rifai. Вміст ХС лПНЩ (ммоль/л) розраховували за фрормулою Фрідвальда (XС ЛПНЩ=3ХC(ХС ЛПВЩ+ТГ/2,2)).

У дослідження не включали жінок фрертильного періоду і старечого віку, хворих з вираженою серцевою недостатністю, перенесеним в анамнезі аортокоронарним шунтуванням чи ендоваскулярним коронарним втручанням.

Статистичну обробку отриманих результатів проводили з використанням пакета програм для статистичного аналізу STATISTICA (версія 6,0). У разі нормального розподілу дані представлено у фрормі середнього значення і стандартного відхилення $(\mathrm{M} \pm \mathrm{m})$. Достовірність відмінностей між групами за кількісними ознаками оцінювали за допомогою t-критерію Стьюдента (в разі нормального розподілу) та критерію ВілкоксонаМанна-Уїтні (в разі розподілів, відмінних від нормального). Відмінності вважали достовірними при рівні значимості >95 \% $(p<0,05)[13]$.

РЕЗУЛЬТАТИ Й ОБГОВОРЕННЯ. Хворі Жінки з ГКСбпST, які мали перименопаузальний тип гормонального статусу (1А), були достовірно на 8,48 року молодшими, ніж пацієнтки з постменопаузальним ендокринним балансом статевих гормонів (1Б) $($ р<0,01) (табл. 1). Середній вік хворих жінок з перименопаузальним типом гормонального статусу становить $(52,29 \pm 1,63)$ року, що загалом узгоджується з даними ААСЕ (2011), відповідно до яких середній вік настання менопаузи в Північній Америці складає приблизно 51 рік [14].

Ми провели аналіз показників жіночих статевих гормонів у порівнюваних підгрупах. Рівні естрадіолу у хворих (1-ша група) і здорових (2-га група) жінок підгрупи А виявились достовірно нижчими порівняно з такими в пацієнток підгрупи Б $((17,24 \pm 1,29)$ пг/мл $(1 \mathrm{~A})$ та $(18,69 \pm 1,59)$ пг/мл (2А) проти $(30,69 \pm 2,77)$ пг/мл (1Б) і $(44,13 \pm 3,3)$ пг/мл (2Б) відповідно, p<0,01), що свідчило про стан відносного естрогенодефріциту в осіб підгруп 1А та 2А. При цьому виразність естрогенодефріциту була достовірно більшою у групі пацієнток із ГКСбпST (1A) порівняно з групою практично здорових жінок (2A) $((17,24 \pm 1,29)$ пг/мл (1A) проти $(18,69 \pm 1,59)$ пг/мл $(2 \mathrm{~A})$, р<0,05) (табл. 1). Середні показники індексу співвідношення ЛГ/ФСГ також були достовірно нижчими у групі пацієнток із ГКСбпST, ніж у практично здорових осіб відповідних підгруп $((0,65 \pm 0,03)$ од. (1A) проти $(0,75 \pm 0,01)$ од. (2A), p<0,05; $(1,64 \pm 0,10)$ од. (1Б) проти $(2,48 \pm 0,26)$ од. (2Б), р<0,01), що свідчило про більш виражені дисгормональні зміни у хворих, на фоні яких виникав ГКСбпST, порівняно $з$ практично здоровими особами. Водночас

Таблиця 1 - Середні значення статевих гормонів у пацієнток із гострим коронарним синдромом без підйому сегмента ST і практично здорових жінок залежно від типу гормонального статусу

\begin{tabular}{|c|c|c|c|c|}
\hline Показник & $\begin{array}{c}\text { Підгрупа 1А } \\
\text { (ЛГ/ФСГ<1, естра- } \\
\text { діол<80 пмоль/л) } \\
\text { n=64 }\end{array}$ & $\begin{array}{c}\text { Підгрупа 1Б } \\
\text { (ЛГ/ФСГ>1, естра- } \\
\text { діол>80 пмоль/л) } \\
\text { n=48 } \\
\end{array}$ & $\begin{array}{c}\text { Підгрупа 2А } \\
\text { (ЛГ/ФСГ<1, естра- } \\
\text { діол<80 пмоль/л) } \\
\text { n=26 }\end{array}$ & $\begin{array}{c}\text { Підгрупа 2Б } \\
\text { (ЛГ/ФСГ>1, естра- } \\
\text { діол>80 пмоль/л) } \\
\text { n=19 }\end{array}$ \\
\hline Середній вік, роки & $60,77 \pm 1,16^{\star \star}$ & $52,29 \pm 1,63$ & $58,64 \pm 2,18^{\star \star}$ & $49,84 \pm 1,84$ \\
\hline Естрадіол, пг/мл & $17,24 \pm 1,29$ **\# & $30,69 \pm 2,77^{\# \#}$ & $18,69 \pm 1,59$ ** & $44,13 \pm 3,31$ \\
\hline ФСГ, МОд/л & $51,37 \pm 4,22^{\star \star \# \#}$ & $22,42 \pm 2,89^{\# \#}$ & $27,57 \pm 2,77^{\star \star}$ & $8,03 \pm 1,09$ \\
\hline ЛГ, МОд/л & $31,80 \pm 2,30^{\star *}$ & $36,80 \pm 5,44^{\# \#}$ & $20,04 \pm 3,57$ & $18,65 \pm 2,86$ \\
\hline ЛГ/ФСГ, од. & $0,65 \pm 0,03^{\star \star \#}$ & $1,64 \pm 0,10^{\# \#}$ & $0,75 \pm 0,01^{\star \star}$ & $2,48 \pm 0,26$ \\
\hline
\end{tabular}

Примітки. Тут і в таблицях 2, 3:

1. * - різниця між показниками підгруп А та Б $(p<0,05)$.

2. ** - різниця між показниками підгруп А та Б $(p<0,01)$.

3. \# - різниця між показниками відповідних підгруп 1-ї і 2-ї груп $(p<0,05)$

4. - різниця між показниками відповідних підгруп 1-ї і 2-ї груп $(p<0,01)$ 
рівень цього показника виявився достовірно меншим в осіб жіночої статі з постменопаузальним типом гормонального балансу як у групі здорових (2A), так і в групі хворих (1A) порівняно з відповідними підгрупами жінок, які мали перименопаузальний тип гормонального гомеостазу (2Б, 1Б) (табл. 1).

Ми провели аналіз поширеності цукрового діабету, куріння та профресійно-шкідливої праці. Було виявлено, що у хворих жінок зі збереженим естрогеновим фоном (1Б) вища поширеність цукрового діабету $((31,25 \pm 5,15) \%(1 Б)$ проти $(18,75 \pm 4,88) \%(1 \mathrm{~A}))$, куріння $((54,16 \pm 7,19) \%(1 Б)$ проти $(37,50 \pm 6,05)$ \% (1А)) та професійношкідливої праці $((89,58 \pm 4,41) \%(1 Б)$ проти $(89,58 \pm 4,41) \%(1 A))$.

Проведено порівняльний аналіз основних показників ліпідного обміну та поширеності атерогенної дисліпідемії в досліджуваних групах. Було з'ясовано, що гіперхолестеринемію реєстрували серед пацієнток із ГКСбпST (1A, 1Б) у 4-5 разів достовірно частіше порівняно 3 практично здоровими жінками відповідних підгруп (2A, 2Б) (р<0,01) (табл. 2). При цьому $(95,31 \pm 2,64) \%$ хворих жінок зі згасанням статевої функції (1А) мали рівень ЗХС, більший 4 ммоль/л, а частота гіперхолестеринемії серед них в 1,3 раза достовірно перевищувала таку в пацієнток з відносно збереженим балансом жіночих статевих гормонів (1Б) $((95,31 \pm 2,64) \%(1 \mathrm{~A})$ проти $(75,00 \pm 6,25)$ \% (1Б), p<0,01). Подібна тенденція простежувалась і в групі практично здорових жінок, в яких переважання частоти випадків гіперхолестеринемії також виявлено на основі естрогенодесріциту ( $>0,05)$ (табл. 2).
Незалежно від типу гормонального статусу середні рівні 3ХС більш ніж на 20 \% були вищими в обох підгрупах хворих із ГКСбпST порівняно з практично здоровими особами відповід-

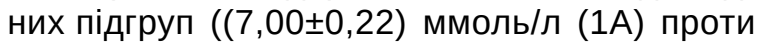
$(5,41 \pm 0,09)$ ммоль/л $(2 \mathrm{~A})$ та $(5,48 \pm 0,20)$ ммоль/л (1Б) проти $(4,46 \pm 0,09)$ ммоль/л (2Б) відповідно, $\mathrm{p}<0,05)$. Водночас у хворих із ГКСбпST з естрогенодефіцитом (1А) виявляли тяжчі порушення ліпідного обміну: середній рівень ЗХС майже на 30 \% перевищував такий же показник у пацієнток, які мали задовільний естрогеновий фрон (2Б) (табл. 3). Незалежно від гормонального статусу в групі хворих із ГКСбпST реєстрували тяжчі зміни ліпідного обміну порівняно $з$ практично здоровими жінками. Зокрема, вміст у крові хворих із ГКСбпST (1-ша група) ХС лПНЩ від 20 до 40 \%, залежно від гормонального статусу, достовірно перевищував відповідні показники в групі практично здорових осіб (2-й) $((4,50 \pm 0,21)$ ммоль/л (1A) проти $(3,18 \pm 0,08)$ ммоль/л (2A) та $(3,44 \pm 0,24)$ ммоль/л(1Б) проти $(2,86 \pm 0,07)$ ммоль/л (2Б), р<0,01). Водночас середній рівень ХС ЛПНЩ був достовірно найвищим у хворих жінок із ГКСбпST $з$ естрогенодеоріцитом $(p<0,05)$ (табл. 3). Аналогічна ситуація простежувалася щодо інших проатерогенних показників, зокрема ХС лПДНЩ (табл. 3). Заслуговує на увагу те, що серед хворих жінок із ГКСбпST з виснаженим гормональним фоном (1А) частка пацієнток зі зниженими значеннями антиатерогенного ХС ЛПВЩ була майже в 1,5 раза меншою порівняно з групою пацієнток, які мали задовільний естрогеновий фон $((37,50 \pm 6,05) \%(1 \mathrm{~A})$ проти $(52,08 \pm 7,21) \%$ (1Б), p<0,01) (табл. 2). Важливо відзначити, що

Таблиця 2 - Поширеність дисліпідемій у пацієнток із гострим коронарним синдромом без підйому сегмента ST і практично здорових жінок залежно від типу гормонального статусу (\%)

\begin{tabular}{|c|c|c|c|c|}
\hline Фактор & $\begin{array}{c}\text { Підгрупа 1А } \\
\text { (ЛГ/ФСГ<1) } \\
n=64\end{array}$ & $\begin{array}{c}\text { Підгрупа 1Б } \\
(Л Г / Ф С Г>1) \\
n=48\end{array}$ & $\begin{array}{c}\text { Підгрупа 2A } \\
(Л Г / Ф С Г<1) \\
n=26\end{array}$ & $\begin{array}{c}\text { Підгрупа 2Б } \\
\text { (ЛГ/ФСГ>1) } \\
\text { n=19 }\end{array}$ \\
\hline ЗХС >4,0 ммоль/л & $\begin{array}{c}\mathrm{n}=61 \\
95,31 \pm 2,64 \text { **\# }\end{array}$ & $\begin{array}{c}n=36 \\
75,00 \pm 6,25^{\# \#}\end{array}$ & $\begin{array}{c}n=6 \\
23,08 \pm 8,26\end{array}$ & $\begin{array}{c}n=2 \\
15,78 \pm 8,36\end{array}$ \\
\hline ХС ЛПВЩ<1,2 ммоль/л & $\begin{array}{c}\mathrm{n}=24 \\
37,50 \pm 6,05^{\star \# \#}\end{array}$ & $\begin{array}{c}\mathrm{n}=25 \\
52,08 \pm 7,21^{\text {\#\# }}\end{array}$ & $\begin{array}{c}n=4 \\
15,38 \pm 7,07^{*}\end{array}$ & 0,00 \\
\hline ТГ>1,7 ммоль/л & $\begin{array}{c}n=47 \\
73,43 \pm 5,52\end{array}$ & $\begin{array}{c}n=22 \\
45,83 \pm 8,19^{\#}\end{array}$ & $\begin{array}{c}n=11 \\
42,30 \pm 9,68\end{array}$ & $\begin{array}{c}n=5 \\
26,32 \pm 10,10\end{array}$ \\
\hline
\end{tabular}

Таблиця 3 - Середні значення показників ліпідного обміну в пацієнток із гострим коронарним синдромом без підйому сегмента ST і практично здорових жінок залежно від типу гормонального статусу

\begin{tabular}{|c|c|c|c|c|}
\hline Показник & $\begin{array}{c}\text { Підгрупа 1А } \\
(Л Г / Ф С Г<1) \\
n=64\end{array}$ & $\begin{array}{c}\text { Підгрупа 1Б } \\
(Л Г / Ф С Г>1) \\
\text { n=48 }\end{array}$ & $\begin{array}{c}\text { Підгрупа 2А } \\
(Л Г / Ф С Г<1) \\
\text { n=26 }\end{array}$ & $\begin{array}{c}\text { Підгрупа 2Б } \\
(Л Г / Ф С Г>1) \\
\text { n=19 }\end{array}$ \\
\hline ЗХС, ммоль/л & $7,00 \pm 0,22^{\star \# \#}$ & $5,48 \pm 0,20^{\#}$ & $5,41 \pm 0,09 *$ & $4,46 \pm 0,09$ \\
\hline ХС ЛПВЩ, ммоль/л & $1,16 \pm 0,05^{\star \#}$ & $1,04 \pm 0,03^{\# \#}$ & $1,24 \pm 0,01$ & $1,33 \pm 0,02$ \\
\hline ХС ЛПНЩ, ммоль/л & $4,50 \pm 0,21^{\star \# \#}$ & $3,44 \pm 0,24^{\# \#}$ & $3,18 \pm 0,08^{*}$ & $2,86 \pm 0,07$ \\
\hline ХС ЛПДНЩ, ммоль/л & $1,19 \pm 0,08^{\star \#}$ & $0,94 \pm 0,07$ & $0,97 \pm 0,02$ & $0,95 \pm 0,04$ \\
\hline ТГ, ммоль/л & $2,60 \pm 0,18^{\star \# \#}$ & $2,04 \pm 0,09^{\#}$ & $1,77 \pm 0,04$ & $1,75 \pm 0,05$ \\
\hline
\end{tabular}


й середній рівень антиатерогенного ХС лПВЩу групі пацієнток із ГКСбпST зі збереженим гормональним гомеостазом (1Б) виявився достовірно нижчим, ніж у групі жінок, які мали естрогенодефріцит (1А) $((1,04 \pm 0,03)$ ммоль/л (1Б) проти $(1,16 \pm 0,05)$ ммоль/л $(1 \mathrm{~A}), \mathrm{p}<0,05)$. Середні рівні ХС ЛПВЩ у групах практично здорових жінок коливалися в межах припустимих значень, проте були достовірно вищими в осіб зі збереженим гормональним фроном $((1,33 \pm 0,02)$ ммоль/л (2Б) проти $(1,24 \pm 0,01)$ ммоль/л (2A), p<0,05) (табл. 3). Таку ситуацію можна пояснити більшою поширеністю серед хворих підгрупи 2Б осіб із цукровим діабетом, курців та жінок, які в процесі роботи мали контакт з ксенобіотиками, здатними істотно знижувати рівень захисних антиатерогенних фрракцій ХС ЛПВЩ, незважаючи на задовільну активність естрогенового захисту.

Гіпертригліцеридемію (>1,7 ммоль/л) майже у 2 рази достовірно частіше реєстрували також у групі хворих жінок із ГКСбпSТ (1А, 1Б). У $(73,43 \pm 5,52) \%$ пацієнток із ГКСбпST, які мали відносний естрогенодефріцит (1А), було виявлено гіпертригліцеридемію, яку реєстрували в 1,6 раза достовірно частіше $((45,83 \pm 8,19) \%)$, ніж у хворих з відносно збереженим гормональним балансом (15) $(p<0,01)$. Аналогічна тенденція, хоча і менш виражена, ніж серед хворих, простежувалась у групі практично здорових осіб. Серед них збільшення тригліцеридів майже в 2 рази частіше виявляли на основі естрогенодефріциту $((42,30 \pm 9,68) \%(2 A)$ проти $(26,32 \pm 10,10) \%$ (2Б), p>0,05) (табл. 2). Незалежно від типу гормонального балансу середні рівні тригліцеридів були достовірно вищими серед хворих жінок із ГКСбпST порівняно з відповідними підгрупами практично здорових осіб $(p<0,05)$ (табл. 3). Порушення гормонального балансу на тлі згасання статевої гормональної активності характеризувалося збільшенням не лише частки осіб з гіпертригліцеридемією, але і її виразності. У групі хворих жінок із ГКСбпST з естрогенодесріцитом (1А) середній рівень ТГ був достовірно вищим порівняно 3 таким без зниження ендокринного фрону $((2,60 \pm 0,18)$ ммоль/л $(1 \mathrm{~A})$ проти $(2,04 \pm 0,09)$ ммоль/л $(15)$, р<0,05) (табл. 3).

Наші дані цілком узгоджуються з даними епідеміологічних досліджень, відповідно до яких 3 настанням естрогенодефіциту в постменопаузальних жінок частіше виявляють більш значне підвищення ЗХС, ТГ та ХС ЛПНЩ [15]. Щодо рівня ХС ЛПВЩ у жінок, то на даний час існують контраверсійні дані, що потребують подальшого вивчення. Переважно значне зниження рівня XC лПВЩ, яке реєструють у пацієнток із ГКСбпST, пов'язують 3 підвищенням серцево-судинного ризику. Водночас у роботах J.-L. Zhou (2010) було продемонстровано те, що, незважаючи на естрогенодесріцит, рівень антиатерогенного ХС ЛПВЩ може залишатися вищим у групі жінок постменопаузального періоду $[11,12]$. У жінок навіть зі збереженим гормональним фоном інфраркт міокарда виникає на тлі поєднання декількох фракторів ризику, з яких найбільше значення мають дисліпідемії, вплив яких посилюється дією ксенобіотиків внаслідок куріння та/або роботи в профресійно-шкідливих умовах.

ВИСНОВКИ. 1. Незалежно від гормонального статусу серед хворих жінок із ГКСбпST, порівняно $з$ практично здоровими, реєструють достовірно вищі поширеність та виразність дисліпідемій.

2. Частка осіб з дисліпідемією та середні значення абсолютних їх показників $€$ достовірно вищими у хворих жінок із ГКСбпSТ з естрогенодефіцитом порівняно з пацієнтками зі збереженим гормональним статусом.

3. В обох групах хворих знижений рівень антиатерогенного ХС ЛПВЩ. Порівняно з жінками з естрогенодесріцитом у перименопаузальних жінок з відносно збереженим естрогеновим фоном достовірно нижчий рівень ХС ЛПВЩ $€$ наслідком вищої поширеності цукрового діабету $((31,25 \pm 5,15) \%)$, куріння $((54,16 \pm 7,19) \%)$ та

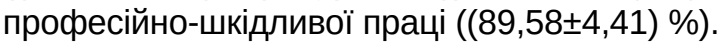

\section{СПИСОК ЛІТЕРАТУРИ}

1. Acute myocardial infarction in women: a scientific statement from the American HeartAssociation / L. S. Mehta, T. M. Beckie, H. A. DeVon, [et al.] // Circulation. 2016. - 133. - P. 916-947.

2. National Heart, Lung, and Blood Institute; American College of Cardiology Foundation; American Heart Association. Implications of recent clinical trials for the
National Chole sterol Education Program Adult Treatment Panel III guidelines/S. M. Grundy, J. I. Cleeman, C. N. Merz [et al.] // Circulation. - 2004. - 110 (2). - P. 227-239.

3. Russell V. Luepker WHO MONICA Project: What Have We Learned and Where to Go from Here? / Russell V. Luepker // Public Health Reviews. - 2012. - 33. P. 373-396. 
4. Нетяженко В. 3. Ішемічна хвороба серця у жінок: особливості фракторів ризику / В. 3. Нетяженко, О. М. Барна // Укр. кардіол. журн. - 2003. - № 2. C. $17-24$.

5. Adiponectin levels, cardiometabolic risk factors and markers of subclinical atherosclerosis in children / P. Arnaiz, M. Acevedo, S. Barja [et al.] // Int. J. Cardiol. 2010. - 138, No. 2. - P. 138-144.

6. Медицина климактерия / под ред. В. П. Сметник. - М., 2006. -847 с.

7. Менопауза: міждисциплінарні аспекти : навч. посіб. / [€. Х. Заремба, М. Р. Гжегоцький, І. С. Шатинська-Мицик та ін.] ; за ред. Є. Х. Заремби. - Львів : АРТ Студія AKME, 2012. - 124 c.

8. Menopause: diagnosis and management. NICE Guidelines, November 2015. https://www.nice.org.uk/ guidance/ng23.

9. Guidelines for the diagnosis and treatment of nonST-segment elevation acute coronary syndromes I J. P. Bassand, C. W. Hamm, D. Ardissino [et al.] // European Heart Journal. - 2011. - 93. - P. 2999-3054.

10. Унісрікований клінічний протокол екстреної, первинної, вторинної (спеціалізованої), третинної (ви- сокоспеціалізованої) медичної допомоги та медичної реабілітації: гострий коронарний синдром без елевації сегмента ST : наказ МОЗ України від 03.03.2016 р. № 164.

11. Serum lipid profile changes during the menopausal transition in Chinese women: a community-based cohort study / J.-L. Zhou, S.-Q. Lin, Y. Shen [et al.] // Menopause. - 2010. - 17. - P. 997-1003.

12. Luz Fernandez M. Postmenopausal women have higher HDL and decreased incidence of low HDL than premenopausal women with metabolic syndrome / M. Luz Fernandez, A. Gabriela Murillo // Healthcare. - 2016. 4. - P. 20; doi:10.3390/healthcare 4010020

13. Біостатистика / [В. Ф. Москаленко, О. П. Гульчій, М. В. Голубчиков та ін.] ; за заг. ред. В. Ф. Москаленка. - К. : Книга плюс, 2009. - 184 с.

14. AACE medical guidelines for clinical practice for the diagnosis and treatment of menopause / N. F. Goodman, R. H. Cobin, S. B. Ginzburg [et al.] // Endocr. Pract. - 2011. - 17. - P. 1-25.

15. Polotsky H. N. Metabolic implications of menopause / H. N. Polotsky, A. J. Polotsky // Semin. Reprod. Med. - 2010. - 28. - P. 426-434.

\section{REFERENCES}

1. Mehta, L.S., Beckie, T.M., DeVon, H.A., Grines, C.L., Krumholz, H.M., Johnson, M.N., Lindley, K.J. ... et al. (2016). Acute myocardial infarction in women: a scientific statement from the American HeartAssociation. Circulation, 133, 916-947.

2. Grundy, S.M., Cleeman, J.I., Merz, C.N., Brewer, H.B., Clark, L.T., Hunninghake, D.B., Pasternak, R.C. ... et al. (2004). National Heart, Lung, and Blood Institute; American College of Cardiology Foundation; American Heart Association. (2004) Implications of recent clinical trials for the National Cholesterol Education Program Adult Treatment Panel III guidelines. Circulation, 110 (2), 227-239.

3. Luepker, R.V. (2012). WHO MONICAProject: What Have We Learned and Where to Go from Here? Public Health Reviews, 33, 373-396.

4. Netiazhenko, V.Z., \& Barna, O.M. (2003) Ishemichna khvoroba sertsia u zhinok: osoblyvosti faktoriv ryzyku [Coronary heart disease in women: features of risk factors]. Ukrainskyi kardiolohichnyi zhurnal - Ukrainian Cardiological Journal, 2, 17-24 [in Ukrainian].

5. Arnaiz, P., Acevedo, M., Barja S., Aglony M., Guzmán B., Carvajal J., Moreno J. Navarrete C., Berríos X. (2010) Adiponectin levels, cardiometabolic risk factors and markers of subclinical atherosclerosis in children. Int. J. Cardiol., 138, 138-144.

6. Smeetnik, V.P. (2006). Meditsyna klimakterika [Climacteric medicine]. Moscow [n Russian].

7. Zaremba, Ye.Kh., Hzhehotskyi, M.R., \& Shatynska-Mytsyk, I.S. (2014). Menopauza: mizhdystsyplinarni aspekty [Menopause: interdisciplinary aspects]. Lviv: ART Studiia AKME [in Ukrainian].

8. NICE Guidelines (2015). Menopause: diagnosis and management. Retrieved from: https://www.nice.org. uk/guidance/ ng23.
9. Bassand J.P., Hamm C. W., Ardissino D., Boersma E., Budaj A., Fernández-Avilés F. (2011) Guidelines for the diagnosis and treatment of non-ST-segment elevation acute coronary syndromes. European Heart Journal, 93, 2999-3054.

10. (2016). Nakaz № 164. Unifikovanyi klinichnyi protokol ekstrenoi, pervynnoi, vtorynnoi (spetsializovanoi), tretynnoi (vysokospetsializovanoi) medychnoi dopomohy ta medychnoi reabilitatsii: hostryi koronarnyi syndrom bez elevatsii sehmenta ST [Order No. 164. Unified clinical protocols of emergency, primary, secondary (specialized), tertiary (highly specialized) care and rehabilitation with non - ST elevation acute coronary syndrome]. Kyiv [in Ukrainian].

11. Zhou, J.L., Lin, S.Q., Shen, Y., Chen, Y., Zhang, Y., \& Chen, F.L., (2010). Serum lipid profile changes during the menopausal transition in Chinese women: a community-based cohort study. Menopause, 17, 997-1003.

12. Fernandez, M.L., \& Murillo, A.G. (2016) Postmenopausal women have higher hdl and decreased incidence of low hdl than premenopausal women with metabolic syndrome. Healthcare, 4, 20-30.

13. Moskalenko, V.F, Hulchii, O.P, Holubchykov, M.V. (2009). Biostatystyka. Pid zahalnoiu redaktsiieiu chlenakorespondenta AMN Ukrainy, profesora V.F. Moskalenka [Biostatistiks. Under the general editorship of Corresponding Member of AMS of Ukraine, Professor Moskalenko V.F]. Kyiv: Knyha plius (in Ukr.)

14. Goodman, N.F., Cobin, R.H., Ginzburg, S.B., Katz, I.A., \& Woode, D.E. (2011). AACE medical guidelines for clinical practice for the diagnosis and treatment of menopause. Endocr. Pract., 17, 1-25.

15. Polotsky, H.N., \& Polotsky, A.J. (2010). Metabolic implications of menopause. Semin. Reprod. Med., 28, 426-434. 
В. В. Процко

\section{ОСОБЕННОСТИ ЛИПИДНОГО ОБМЕНА У ЖЕНЩИН С ОСТРЫМ КОРОНАРНЫМ СИНДРОМОМ БЕЗ ПОДЪЕМА СЕГМЕНТА ЗТ В ЗАВИСИМОСТИ ОТ ГОРМОНАЛЬНОГО СТАТУСА}

\section{Резюме}

Вступление. Роль нарушений обмена липидов в процессе атерогенеза установлено давно. Мало известно о влиянии дислипидемий на развитие ишемической болезни сердца (ИБС) у женщин. Существует представление о том, что влияние эндогенных эстрогенов в течение фрертильного периода жизни женщин замедляет манифестацию атеросклероза у них и до наступления менопаузы частота случаев ИБС у женщин ниже. Особую опасность в развитии ИБС у женщин составляют гиперхолестеринемия или атерогенная дислипидемия и связанный с ней риск макрососудистых поражений, несмотря на длительное бессимптомное течение и значительную распространенность в женской популяции.

Цель исследования - провести сравнительный анализ показателей липидного обмена у пациенток с острым коронарным синдромом без подъема сегмента ST (OKCбпST) и практически здоровых женщин в зависимости от гормонального статуса.

Методы исследования. Обследовано 157 женщин в возрасте 35-72 лет (средний возраст -

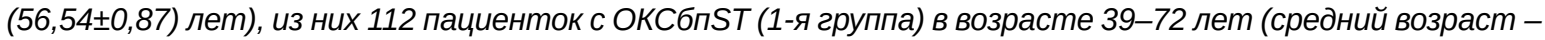
$(58,52 \pm 0,99)$ лет) и 45 практически здоровых женщин в возрасте 35-71 года (средний возраст - $(52,58 \pm 1,58)$ лет). Определяли уровень женских половых гормонов. Изучали показатели липидного обмена у женщин. В зависимости от типа гормонального статуса женщины 1-й и 2-й груп были распределены в подгруппы A и В: $1 A$ - 64 женщины в возрасте 39-72 лет (средний возраст - $(60,77 \pm 1,16)$ лет) с ОКСбпST, $2 A-$ 26 практически здоровых лиц в возрасте 42-71 года (средний возраст - $(58,64 \pm 2,18)$ лет) с гормональными признаками постменопаузы: уровнем эстрадиола <80 пмоль/л (21,79 па/мл) и индексом ЛГ/ФСГ<1; 15 - 48 женщин в возрасте 35-65 лет (средний возраст - $(52,29 \pm 1,63)$ лет) с ОКСбпST, 25 - 19 практически здоровых лиц в возрасте 35-58 лет (средний возраст - $(49,84 \pm 1,84)$ лет) с уровнем эстрадиола >80 пмоль/л (21,79 пг/мл) и индексом ЛГ/ФСГ>1.

Результаты и обсуждение. Почти все больные женщины подгруппы 1 А имели уровень общего холестерина более 4 ммоль/л, что в 1,3 раза достоверно превышало такой же показатель у пациенток подгруппы $1 Б((95,31 \pm 2,64) \%(1 A)$ против $(75,00 \pm 6,25) \%(15))$. Средний уровень холестерина липопротеинов низкой плотности достоверно наивысший у женщин подгруппы $1 A((4,50 \pm 0,21)$ ммоль/л $(1 A)$ против

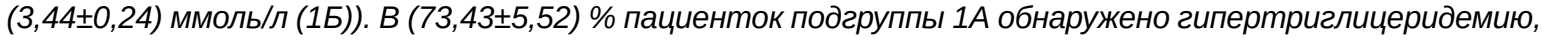
которую в 1,6 раза достоверно чаще регистрировали $((45,83 \pm 8,19) \%)$, чем у больных подгруппы 1Б. Доля пациенток с пониженными значениями холестерина липопротеинов высокой плотности была почти в 1,5 раза меньше в подгруппе 1 A $((37,50 \pm 6,05) \%(1 A)$ против $(52,08 \pm 7,21) \%(15))$. Средний уровень холестерина липопротеинов высокой плотности в подгруппе 1Б был достоверно ниже по сравнению с подгруппой 1 A $((1,04 \pm 0,03)$ ммоль/л (1Б) против $(1,16 \pm 0,05)$ ммоль/л (1A)). Распространенность сахарного диабета $((31,25 \pm 5,15) \%)$, курения $((54,16 \pm 7,19) \%)$ и профессионально-вредной роботы $((89,58 \pm 4,41) \%)$ оказалась достоверно выше у пациенток подгруппы 1Б.

Выводы. У больных с ОКСбпST, независимо от гормонального баланса женских половых гормонов, больше распространенность и выраженность дислипидемий по сравнению со здоровыми лицами. Эстрогенодефицит в постменопаузальных женщин с ОКСбпST приводит к тяжелым нарушениям липидного и жирового обмена, способствующим развитию ОКСбпST. Ниже уровни холестерина липопротеинов высокой плотности, антиатерогенного холестерина липопротеинов высокой плотности у женщин с сохраненным эстрогеным фоном, по сравнению с пациентками с эстрогенодефицитом, является следствием высшей распространенности сахарного диабета $((31,25 \pm 5,15) \%)$, курения $((54,16 \pm 7,19) \%)$ u профрессионально-вредной работы $((89,58 \pm 4,41) \%)$ наряду с наличием традиционных фракторов риска ОКСбпST у этих женщин.

КЛЮЧЕВЫЕ СЛОВА: острый коронарный синдром; женщины; эстрогенодефицит; липидный обмен; дислипидемии. 


\section{FEATURES OF LIPID METABOLISM IN WOMEN WITH NON ST ELEVATION ACUTE CORONARY SYNDROME DEPENDING ON THE HORMONAL STATUS}

\section{Summary}

Introduction. The role of lipid metabolism disorders in the process of atherogenesis has long been established. It is known little about the effects of dyslipidemia on the development of coronary artery disease in women. There is a perception that the effect of endogenous estrogens during the fertile period of woman's life slows down the manifestation of atherosclerosis in women and before the onset of menopause, the incidence of CVD in women is lower. Hypercholesterolemia or atherogenic dyslipidemia is a particular danger in the development of CVD in women and the risk of macrovascular injury associated with it is due to the long asymptomatic course and significant prevalence in the female population.

The aim of the study - to conduct a comparative analysis of lipid metabolism in women with acute coronary syndrome without ST segment elevation (STEMI) and practically healthy women, depending on the hormonal status.

Materials and Methods. We examined 157 women aged 35-72 years (average age 56.54 \pm 0.87 years). Among them, 112 female patients with STEMI (group 1) aged 39 to 72 years (average age 58.52 \pm 0.99 years). The comparison group (group 2) were 45 practically healthy women aged 35 to 71 years (average age $52.58 \pm 1.58$ years). The levels of female sex hormones were determined. The lipid metabolism indices in women were measured. Depending on the type of hormonal status, women of the 1 and 2 groups were divided into subgroups $A$ and $B$

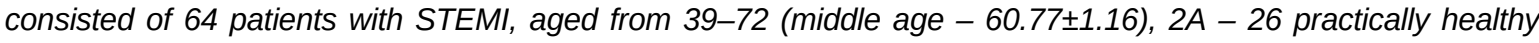
women 42-71 years (average age $58.64 \pm 2.18$ years) with hormonal signs of postmenopause: estradiol le$\mathrm{vel}<80 \mathrm{pmol} / \mathrm{l}(21.79 \mathrm{pg} / \mathrm{ml})$ and $\mathrm{LH} / \mathrm{FSH}<1$ ratio index. The subgroup $1 B$ included 48 female patients with non

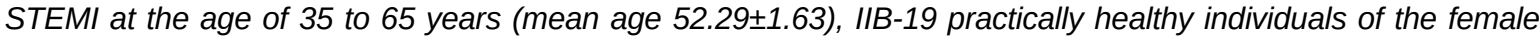

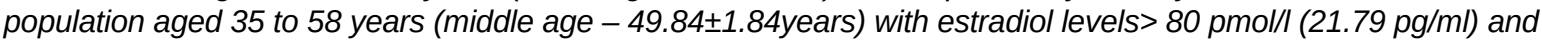
a ratio of $L H / F S H>1$.

Results and Discussion. Almost all female patients of the IA subgroup had a level of total cholesterol level more than $4 \mathrm{mmol} / \mathrm{l}$, which was 1.3 times significantly greater than that of IB subgroup (95.31 $\pm 2.64 \%$ (IA) vS $75.00 \pm 6.25 \%(I B))$. The mean level of $L D L$ cholesterol is significantly higher in women IA subgroups (4.50 \pm 0.21 $\mathrm{mmol} / \mathrm{I}(\mathrm{IA})$ vs $3.44 \pm 0.24 \mathrm{mmol} / \mathrm{I}(\mathrm{IB}))$. In $73.43 \pm 5.52 \%$ of the IA subgroup, hypertriglyceridemia was detected, which was 1.6 times more likely to be registered $(45.83 \pm 8.19 \%)$ than in patients with IB subgroups. The proportion of patients with lowered LDL cholesterol was almost 1.5 times lower in the IA subgroup (37.50 $\pm 6.05 \%$ (IA) vs $52.08 \pm 7.21 \%(I B))$. The mean HDL cholesterol level in the IB was significantly lower in comparison with the subgroup $1 A(1.04 \pm 0.03 \mathrm{mmol} / \mathrm{l}(1 \mathrm{~B})$ versus $1.16 \pm 0.05 \mathrm{mmol} / \mathrm{l}(\mathrm{IA})$. Diabet (31.25 $\pm 5.15 \%)$, smoking (54.16 $\pm 7.19 \%)$ and occupationally hazardous labor (89.58 $\pm 4.41 \%)$ was significantly higher in patients of the subgroup $1 B$.

Conclusions. In women with STEMI, regardless of the hormonal balance of female sex hormones, there is a greater prevalence and severity of dyslipidemia compared with healthy individuals. Estrogen deficiency in postmenopausal women with STEMI cause severe lipid and lipid metabolism disorders, which contributes to the development of acute coronary syndrome. Lower levels of HDL cholesterol in patients with estrogen retained estrogen compared

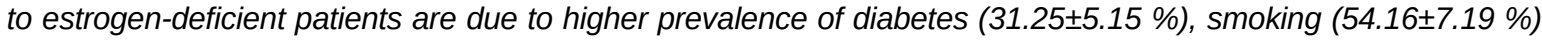
and occupationally harmful work (89.58 $\pm 4.41 \%)$, along with the presence of traditional risk factors of STEMI in these women.

KEY WORDS: acute coronary syndrome; women; estrogen deficiency; lipid metabolism; dyslipidemia.

Отримано 23.10.17

Адреса для листування: В. В. Процько, Львівський національний медичний університет імені Данила Галицького, вул. Пекарська, 69, Львів, 79010, Україна, е-mail: VasyI_Protsko@meta.ua. 